\title{
What is the philosophy of education needed in the XXI century?
}

\section{KEYWORDS}

philosophy of education, educate to unknown, digitization, global teenagers, VUCA world

\begin{abstract}
Tatiana Krawczyńska-Zaucha, What is the philosophy of education needed in the XXI century? Culture - Society Education no. 2(18) 2020, Poznań 2020, pp. 467-478, Adam Mickiewicz University Press. ISSN 2300-0422. DOI 10.14746/kse.2020.18.17.2.
\end{abstract}

The last decades have witnessed constant changes and reforms in education in many countries. The paradox of these changes is that they require further changes and transformations and further reforms. Education systems do not correlate with the needs of humanity in the 21 st century, nor with the emerging new world view. This article aims to examine education from the global perspective of the world of digitization in which we live and to find an answer to the question what is the purpose of education in the 21 st century. From the analyses of different pedagogical trends and philosophical assumptions underlying them, a conclusion will be drawn about the need for a philosophy open to new challenges in today's educational reality in order to achieve this goal. This article will address key issues of the VUCA world concerning education such as digitization, educate to the unknown, the phenomenon of global teenagers and the development of robotics.

Institutionalisation and egalitarianism have, paradoxically, reduced education to the role of an area encapsulated in huge volumes of bureaucratic procedures, simultaneously depriving it of the unbearable lightness of passion and the impatience of curiosity. Currently the debates regarding education are focused around its

\footnotetext{
* ORCID: 0000-0001-6530-4206.
} 
form, has been highly institutionalised, and the content is subject to direct political and economic interests. While the quality is a part of the form of education, it is left on the margin of bureaucratic activities. One may be so bold to state, that history made a full, sad circle - despite the fact, that education is universally available, it does not fulfil its basic role of enlightening and stimulating minds, and it fades into oblivious obscurity, and distortion, for the sake of coerced, while short lasting memorisation. Even Rawls, who postulated a "fair equality of opportunity" (Rawls, 1971: 72) for children of social classes and circles, could not foresee, that the access to education is not necessarily equal to motivation for acquiring knowledge. Therefore, what was omitted, or missed out?

In order not to get lost in the maze of meanings and approaches towards pedagogy and education, one should return to the source. Paidagogos (gr.) is someone responsible for leading children, managing their development and education, and taking care of them (Śliwerski, 2019: 15). Philosopher, Radim Palouš, indicates with even more strength, that the essence of pedagogy is that which can be found in the suffix of (gr.), derived from agein - to lead, or age - lead upwards (Palouš, 1991: 16-17). Therefore, pedagogy can be defined as "all conditions, processes and actions that support the development of an individual to achieve their full capabilities" (Kwieciński, Śliwerski, 2019: 7).

Education however, is derived from Latin $e$-duco, where $e$ is an affix meaning a movement outwards, while duco means to lead. The majority of translations is focused on the second component, highlighting that the meaning of education is to lead, to educate, to school. However, in order to understand the essence of education, one must consider the entire word with the $e$ affix, emphasising on the movement from the inside to the outside. Then, education appears as extracting from the inside of the students, their personal resources, talents and strengths, allowing them to use them in the world (Krawczyńska-Zaucha, 2020: 68).

Coming from such, currently inapparent perspective, all pedagogical and educational actions should, of nature, focus on leading "upwards" and extracting that which is within the student, allowing him to live a life filled with opportunities, use own potential, strengths and talents. The aforementioned can be accomplished through favourable company of the pedagogue within the process of learning self and experiencing the world, who shares knowledge with the student and sparks cognitive and scientific curiosity.

While pedagogy is focused on the individual and on building a creative pedagogue - student relation, education is a systematic and organised action encompassing all levels of education (cf. Kwieciński, Śliwerski, 2019: 7). However, in the world of today, one cannot limit to the institutions that are strictly responsible for 
education. Educational roles are assumed by the media, mass events, the world of advertisement and marketing, or idols popular among youth, creators of peculiar subculture. An important, if not the most important, role is played by the Internet network wrapped around the world. Not only due to social networks and algorithms, which can actually impact the choices of people, and are difficult to handle probabilistically (Fry, 2019). Current generations are in fact the first, who have full access to the entire mankind knowledge, developed through millenia. Never before had anyone had such an opportunity. In the past, knowledge and achievements were local, and would spread through months, or even years. Now, all we have to do is perform appropriate research in the Internet and Newton's Philosophiae naturalis principia mathematica or Darwin's On the Origin of Species in original versions may appear on the screen in just a few seconds.

Therefore, the role of education ${ }^{1}$, its aim, is to prepare the student for living in the world with a creative approach, open towards his abilities and potential. However, it is easy to see, that current education is focused on replicative transfer of knowledge of conventional areas of sciences, without considering the interests of the student, his talents and strengths. Ken Robinson grasped the essence of current education, in a vivid description of a student production line, who, without their consent is injecting them with an appropriate portion of knowledge, in order to receive another portion of identical, however, frustrated employees, prepared to fulfil the tasks given by superiors, during working hours and even beyond that (Robinson, 2012). Simultaneously, the 2019 Report on non-public schooling in Poland, indicates, that the number of all non-pubic educational institutions in Poland had grown since 2014 until 2018 by $17,15 \%$, while the number of students attending within the same period increased by 29,73\% (Our Kids Report, 2019: 8). The data indicates a dynamic development of non-public education and its expansion in the general educational system in Poland. The public sector displays a reverse tendency. The 2014-2018 period results in a decreasing tendency both regarding the number of public schools during all education periods, as well as, regarding the number of students that attend these institutions. Additionally, it translates to the decrease of the general participation of public education in the country (Our Kids Report, 2019: 8). There are many causes to that, however, one must quote one of the report's conclusions:

It seems that the non-public sector provides an oasis for many families, where children can find a secure environment, support (also professional in the form of speech and language

1 The presented inquiry shows that education is organised pedagogical actions taken on all levels of the state, therefore, in the following part of the article, the words education and pedagogy will be treated as synonymous. 
therapists, psychologists), where the child is recognised not only for grades and academic successes, but where the comprehensive development of children is cared for, and the stress is replaced with happiness and valuation (Our Kids Report, 2019: 38).

Non-public education properly responds to the educational needs of the $21^{\text {st }}$ century human. It proposes a different philosophy in the approach towards teaching and towards the student. It takes care of "comprehensive development", learns to look at self and own achievements in a positive way, proposes cooperation and an attitude in favour of individual support in developing talents and interests. Additionally, all of the above is is placed within a different world overview. Hence the fact, that the $21^{\text {st }}$ world is constituted by constant change, without the sluggish bureaucratic machine, non-public and social schools are much more able to adjust to the changing needs of students, and expectations of their parents, as well as, tailor the educational offer for them.

Public education is far behind in applying flexible solutions. It is set in a world, the stability of which is sanctioned by hierarchy, established structure and assigned function, being an image of the industrial era of the $18^{\text {th }}$ and the $19^{\text {th }}$ century. Industrial revolution allowed to go from the work of human hands dependent on the weather and the will of God, to large scale manufacturing. Additionally, it changed the thinking of people about themselves, proving, that it is more clever and more effective to accomplish things with the intellect rather than human hands. The application of steam engines in various industry branches relocated entire groups of farmers from fields to suburban factories, where their miserable image provoked the educated and rich to improve their life. The primary principle was the wider access to education, and the key argument - increased efficiency of workers possessing basic skills of reading, writing and calculus. In such hierarchic world, a model of authoritarian education emerged, based on passing on knowledge, that was to be repeated, until it was memorised, just like instructions. The teacher is the one with the knowledge, and the student - lower in the hierarchy, is to listen to the pedagogue and learn. In such model, the aims of teaching are beyond the student, it is not important what his interests and abilities are, what is important is the model of teaching, the knowledge "package", which must be learned, in order to become useful to the society. A given model should be identical for all students from an appropriate social class, such education is easiest to maintain on all levels (cf. Kosiorek, 2010: 146). Therefore, students are not expected to be creative, innovative, or display critical thinking, the key is to learn the given information, step by step, to master the entire knowledge in accordance with the appropriate model. Meeting the requirements placed before the student yields a diploma - a formal 
acknowledgement regarding the achieved level of education. One must highlight, that the package is treated as the "torch for education", for which students are supposed to be thankful. The degree of hierarchy determines the intensiveness of gratitude and the direction of influence: the student is influenced by the teacher, the teacher is influenced by the principal, the principal is influenced by the curator, etc. The order had been established and the attempt to change or readjust is treated like anarchy. The hierarchic world view with the established order and ascribed positions results from the adopted philosophy of man. The empirical and behavioural approach assumes, that learning the generalised laws that determine the educational processes, will allow, on the basis of a sufficient number of empirical data, to design and apply a peculiar conveyor belt of education, producing more and more "educated students". Behaviourism will provide the appropriate stimuli directing behaviour so that one can achieve, previously programmed results. The defence wall of this world order is the belief, that it should be retained unconditionally, and those who oppose it must be excluded (cf. Hejnicka-Bezwińska, 1995).

A crack in the wall of the authoritarian approach in pedagogy was surely brought by the beginning of the $20^{\text {th }}$ century. An unspoken nightmare that men put onto men, upset the marble monument of the usefulness of good education and even education at all. On the one hand the world view that emerged after the wars, and even, alas, using its "scientific achievements", announced the technological era. On the other hand, the philosophy of man of the $20^{\text {th }}$ century would highlight the drama and lack of reason for human existence despite the possibilities spread before by the developing world. The quick progress appearing in physical sciences, and biological ones, possibilities and result that had not been seen previously, which this world made possible, changed the hierarchical world view into a world of unlimited possibilities achieved due to science and involvement in the consequent strive for assumed aims.

The tragedy of two wars affected the appearance of the pedagogical trends: existential pedagogy trends, which place emphasis on the peculiarity and particularity of human existence, highlighting its mutability; and the trend of anti-authoritarian pedagogies, presented as opposition against authoritarian education, which could lead to Holocaust and the personalistic trend in pedagogy, highlighting the value and freedom of each human being.

Existential pedagogy in various instances, turns attention to human individualism. However, as highlighted by Heidegger, the crowd buries the individual in an anonymous mass, enforcing conventional models of behaviour (Heidegger, 1931: 167), while the man always feels alienated from this world (Camus, 1971: 93), it is possible to become self due to reflection (Jaspers, 1932: 253) and creative action 
(Marcel, 1962: 186). The novum of the philosophy of man in existential pedagogy, in comparison to authoritative pedagogy, consists of placing human freedom in the center, as it constitutes a feature distinctive from the remaining beings, and even, allowing the freedom of an individual and the ability to decide about self. Such outlook definitely goes beyond the fundamental approach of authoritarian pedagogy and allows for the establishment of further educational approaches: anti-authoritative and personalistic pedagogy. They complement the existential theory of man as a holistic approach postulate, without bias and reductionism. According to personalistic pedagogy, education should allow for the development of the entire person, as "education is an assortment of processes, allowing the human being to find themselves in their humanity" (Schaller, 1977: 248). This finding oneself in own humanity is accomplished firstly due to own nature, however, afterwards it is necessary to open oneself towards culture: adopting features and skills allowing for the personalisation of individuals, directing them on a path of autonomous and consistent choices. This is the main aim of the described pedagogy.

A similar approach is characteristic of the trend of anti-authoritarian pedagogies also brought about by the feeling of despair over the humanity actions during World War 2. Initially, its creator Adorno, postulated that pedagogy should be anti-authoritarian in this sense, so that it would educated new society for live without the need to apply violence, so that the Auschwitz nightmare would not repeat. He called for teachers to create a pedagogy of tolerance and love (Adorno, 1978), which would favour the creation of a society based on equality, justice and well-being (Śliwerski, 2019: 536). Adorno highlighted the necessity of systemic changes in education allowing for such pedagogical approach. "An important postulate for anti-authoritarian pedagogues has become the unveiling of all institutional barriers, blocking the individual [...] from the ability to build identity" (Śliwerski, 2019: 537). Anti-authoritarian pedagogy is focused on a free development of the child's personality (Śliwerski, 2019: 538), without understatements, taboos or issuing precise instructions and expecting unconditional obedience. The teacher builds own authority on the relation created mutually with the child, where the child determines the paths of interests, following own passions. A pedagogue led by care and filled with knowledge, follows the child. There is no need to apply coercive measures or physical violence, because the student must not coerce himself to study something, that does not interest him. The student-teacher relation is built on mutual trust, building partnership and dialogue. The children do not feel fear of not being able to fulfil tasks, as the responsibility for acquiring knowledge and learning is placed upon them. This favours building the attitude based on the feeling of agency and responsibility for own life and own choices, simultaneously 
strengthening internal motivation. It seems that anti-authoritarian pedagogy is referring to humanism, it is applied interchangeably with the name humanistic pedagogy ${ }^{2}$, and it is also based on personalism and libertarianism. It is difficult to clearly determine the borders of the aforementioned educational trends, as they intertwine with each other. Still, without ascribing each of them directly to one particular philosophy, one may be tempted to characterise it for them altogether. Such philosophy of man is based on the Aristotelian postulat, that humans have natural inclinations for good, and happiness may be found inside, if the individual is skilled (Aristotle, 1997: $1094 \mathrm{~b} 27 \mathrm{n}$ ). The child possesses a potential, which is to be extracted and developed by teaching, particularly in the natural environment (Rousseau). It should be conducted in respecting the students liberty, supporting his creativity and cooperating with others (Dewey). The child's personal freedom is limited by the freedom of another man (Locke), and the openness towards the world and passion of learning it may transform into the ability of an adult to practice science (Schulz, Gopnik, 2004: 27).

The examples of schools, programmes, or even state education systems, that accomplish humanistic pedagogy with coherence and objectively measurable success, are numerous. An example may be the Summerhill school created by Neill in 1924 in England, as it became a model for democratic schools worldwide, and its publications made an enormous impact on the discourse in permissive education worldwide ${ }^{3}$. It radically discarded any enforcement of a personality on the child in an attempt to "shape" the child's character. He thought that both parents and teachers do not educate children, but manipulate them to achieve own goals or train them in own image (Neill, 1975: 20-22). He postulated treating children like partners and encouraged to build harmonic relationships between the world of children and the world of adults. Such attitude demands a radical rebuilding of the philosophy of man. Adopting the assumptions that the child is free and good by nature, that there is nothing to be corrected, but there is space to allow the child for harmonic development in a safe environment filled with acceptance. Neill introduces the concept of self-regulation, meaning that the child is open towards own organism and needs, and can independently regulate satisfying them, while the role of the adult is to make it possible. The aim of education is man, fully free, filled with harmony, coherent, and aware of who he is, what he can accomplish, and who he wants to become as an adult (Neill, 1969: 40). It is worth highlighting,

\footnotetext{
${ }^{2}$ In the literature, one may find a synonymous approach as well as a distinctive one. Due to their philosophical roots, they will be treated as synonymous in the article (Januszewska, 2002).

3 The Summerhill schol is treated both as an example of the anti-authoritarian and humanist trend (Śliwerski, 2019: 541; Januszewska, 2002).
} 
which often becomes an accusation against humanistic pedagogy: freedom does not mean lawlessness and treading over the principles and other people. Freedom is one of the greatest human values and as it is, it contains i.a. equality, internal and external ability to be self and self-realisation of own natural talents, but also respecting the autonomy and sovereignty of others (Śliwerski, 2019: 541). Here it is difficult not to hear Rawls' postulates on retaining liberty and striving for strengthening own good, which simultaneously maintains the system of striving for the common good (Rawls, 1994: 214), or the freedom philosophy by Steiner, based on which, a pedagogy was created, according to which schools in Europe and the entire world are managed (Steiner, 1984).

The most well known state educational system, that was drastically rebuilt in but over a dozen of years, is Finland. The country placed exceptional emphasis on appropriate, theoretical and practical, preparation of teachers for their professions. Without digging into the details that can be found in a broad array of literature, it is worth mentioning that creating a new system of state education, it was built on a peculiar philosophy of man, along with all visible values, clear to all: partnership, respect, collaboration, freedom, mutual responsibility. The system of education does not present students and teachers with theoretical requirements, but consequently and coherently implements these values in real life. The Finnish say: "We may prepare the child for exams or life. We choose the latter". In result, by sparking passion, creativity and the feeling of agency among students, they achieve both aims at the same time: the children pass tests with the highest results worldwide, and are happy people who take the best out of life (PISA, 2000, 2003, 2006).

The aforementioned pedagogical trends may be observed currently in various instances, sometimes pure, sometimes mixed. They evolved proportionally to the time of distancing from the war tragedies, in order to orient around highlighting the freedom of man, allowing the individual for a comprehensive development of own personality, talents and interests, and the entire transfer of knowledge to be individualised as much as possible, despite it being presented to groups. Actions and attitudes, that in some educational options based on a particular approach to a human in a given world image seem impossible, were accomplished fully in others. The adopted reality overview along with the approach towards the human based on particular beliefs and directed with a selected set of values determines actions.

Here, it is necessary to broaden the perspective and an overview, what world image emerges from the current reality. In the 1990s, Classmate.com, the first social network was created. Twenty five years later, only three largest social portals focus more than 5 billion active users from the entire globe (Kallas, 2019). Algo- 
rithms used in the Internet collect enormous amounts of personal data about the user. Personalised ads, displaying contents tailored to user interests or suggested content that is "liked by users such as You" are but few examples, how one may influence the behaviour and decisions of more than a half of humanity (Fry, 2018: 61-66). Network access allowed for an emergence of a new category of youth, the so-called global teenager (de Mooij, 2013: 13). It is a generation of teenagers that, despite of living in various parts of the world, e.g. Tokyo, New York, Paris, Singapore or Warsaw, are much more similar to each other than to their parents, or other generations among which they were raised, and have lived (de Mooij, 2013: 13-14). Global teenagers dress according to the same trend, listen to the same music, watch the same YouTube movies, eat junk food just as their peers from the other side of the globe, they declare similar, global values (de Mooij, 2013: 14). The man of today lives in a global era of internet and is involved in its governing algorithms. The network affects not only the behaviour of people, but also changes the identity of the $21^{\text {st }}$ century man. But that is not all.

Despite the fact that 25 October 2017 was surely one of the days of another great revolution in the history of mankind, few people in Poland know what had happened then. On that day, Sophia received official Saudi-Arabian citizenship, leaving a mark in history, as the first robot that had received citizenship (Hatmaker, 2017). Humanity, fed with films about robot revolts, is afraid to include humanoids in own societies. However, the robots themselves are not a challenge the humanity must tackle, but the robotization of labour (Harari, 2018: 101-105). Automated production or services will be able to employ but a permille of persons they employ now. What will the common man do at this time? What must he learn and what knowledge must he posses? These are the question standing before $21^{\text {st }}$ century education, reaching down to the philosophy of the world and the philosophy of $\operatorname{man}^{4}$.

Evidence for the fact that young people need entirely new skills, which the school does not shape properly, come not only from the observation of everyday life and the opinions presented in the media. The World Bank study shows that the so-called soft-skills are the most deficit assortment of skills pursued by employers (World Bank Report, 2011: 13). Student and, afterwards, a university student, absorbs only theoretical knowledge, without learning practical skills, and they are taught them only in workplaces. Similar with the entire assortment of social skills:

\footnotetext{
${ }^{4}$ Also ethics in the aforementioned examples, however, it is not the place for such considerations in the article.
} 
communication, critical thinking, problem solving, project work, team cooperation, etc.

It seems, that in the light of the above examples, the question regarding what education the mankind needs in the $21^{\text {st }}$ century, seems to be but a rhetorical one, as the answer appears clear. The main trend in education should be selected on the basis of the surrounding world image, but also within the awareness of how this world image will emerge in the close future. The world of today does not correspond with the authoritarian pedagogy that, despite being criticised by decades, is still holding well within the educational systems of many countries. Education in the spirit of obedience, the sole correct answer to the given questions, and primarily, replicating knowledge and world view "packets" in the heads of subsequent groups of students are not, and cannot be an answer to the digital world of network in the $21^{\text {st }}$ century. Therefore it is important to answer the question on the current aim of education. If it is preparing to living in a world, which is a world of a global network and ever persistent algorithms, suggesting decisions to individuals, in a world of perpetual and indeterminate changes, in a world who presents humanity with challenges, that have never been seen before, in a world where, the irony, children and youth are in some aspects more agile and efficient in navigating the world, the answer must be sought after within the trends of pedagogies based on liberty and focus on achieving full humanity by each student. Only education based on a philosophy that postulates, that man is good by nature, has no deficiencies, only possibilities and potential, access to which must be provided, based on own talents and passions, opening the path to perpetual development, to finally lead to the fullness of humanity, will prepare young people to live in the digital world of the $21^{\text {st }}$ century, where all boundaries are blurred out, however, new criteria emerge. Such education for the digital age man will be a promise of a complete life, a life where man applies own skills, talents and potential, engaging in that which is authentic and important to him (Seligman, Csikszentmihalyi, 2000: 11). Philosophy of man being the foundation of the $21^{\text {st }}$ century education, must create new, but flexible boundaries, realising that skills and passions of a students, previously out of its boundaries, may prove crucial in the future. This philosophy must indicate values, not only teaching about them, but giving an example in everyday life. Currently, young generations question values not for their own sake but because they remain values in theory. The youth needs a moral spine chosen out of freedom, instead of forced by the strength of tradition and coercion: "It was always like this so you must be like that". The digital era beginning man is prone to getting lost in own identity, because education offers him solutions and the knowledge of a previous generation, and education is set to teach that which was, and not that which 
is. Educational systems are usually passing the knowledge of the previous generation. Until now, the practice had sufficed. However, the world of the $21^{\text {st }}$ century is rushing too fast. Those responsible for education must be aware that currently, education teach towards the world that is not yet in existence. We are educating towards the unknown (Furr, Dyer, 2014). The global COVID-19 pandemic experience places well within this image. In just a few weeks, the world found itself in a new reality, to which the humanity had no chances to prepare. For two decades, in business, management and education, there are debates about the VUCA world (acronym for volatility, uncertainty, complexity, ambiguity) (Krawczyńska-Zaucha, 2019: 223-224), listing various examples for the constitutive elements. However, only the international quarantine and increasing challenges before the educators, children and parents, truly convinced humanity, that the changes in the world of today appear unexpectedly and on an enormous scale. This unprecedented event revealed our flaws, erroneous premises and inadequate aims of education. It also provided a question about a philosophy which is at its foundation, regarding the adequacy of adopted premises on the surrounding reality.

The world of the $21^{\text {st }}$ century poses many changes both before philosophy and education. It is incredibly important for philosophy in the VUCA reality to be open, and not simply look back, looking pointers in past solutions for issues previously unknown, but to boldly create future, to be a wave that would denote new directions of the development of sciences and thinking trends. One that will boldly face the unknown. That lied at the base of its beginnings, the love for wisdom is nothing else but life filled with curiosity and passion, exactly what the $21^{\text {st }}$ century man needs to experience.

\section{Bibliography}

Adorno T.W. (1978), Wychowanie po Oświęcimiu, „Znak”, no. 285.

Arystoteles (1996), Etyka nikomachejska, trans. D. Gromska, in: Artystoteles, Dzieła wszystkie, vol. 5, Warszawa.

Camus A. (1971), Eseje, trans. J. Guze, Warszawa.

Fry H. (2019), Hello world. Jak być człowiekiem w epoce maszyn?, Warszawa.

Furr N., Dyer J.H. (2014), Leading Your Team into the Unknown, „Harvard Business Review”, 12, https://hbr.org/2014/12/leading-your-team-into-the-unknown [access: 16.11.2019].

Harari Y.N. (2018), 21 lekcji na XXI wiek, Warszawa.

Hatmaker T. (2017), Saudi Arabia bestows citizenship on a robot named Sophia, https://techcrunch. com/2017/10/26/saudi-arabia-robot-citizen-sophia/?guccounter=1\&guce_referrer_us=aHR0c HM6Ly9lbi53aWtpcGVkaWEub3JnLw\&guce_referrer_cs=NcvPuHe3ugg3L7IVs1uvJA [access: 15.11.2019]. 
Heidegger M. (1931), Bycie i czas, trans. B. Baran, Warszawa.

Hejnicka-Bezwińska T. (2015), Praktyka edukacyjna w warunkach zmiany kulturowej, Warszawa.

Januszewska E. (2002), Dojrzewanie do wolności w wychowaniu. Rzecz o A.S Neillu, Warszawa.

Jaspers K. (1932), Philosophie, vol. 1-2, Berlin.

Kallas P. (2019), Top 15 Most Popular Social Networking Sites and Apps, https://www.dreamgrow. com/top-15-most-popular-social-networking-sites/ [access: 15.11.2019].

Kosiorek M. (2010), Pedagogika autorytarna a podejście włączające w procesie kształcenia ucznia ze specjalnymi potrzebami edukacyjnymi, „Przegląd Badań Edukacyjnych”, 10-11, pp. 143-151.

Krawczyńska-Zaucha T. (2019), A new paradigm of management and leadership in the VUCA world, „Scientific Papers of Silesian University of Technology Organization And Management Series”, 141, pp. 221-230.

Krawczyńska-Zaucha T. (2020), Przywództwo edukacyjne jako fundament zarzadzania oświata w świecie Vuca, in: Edukacja XXI wieku. Strategie zarządzania i kierunki rozwoju, ed. T. Krawczyńska-Zaucha, Kraków.

Kwieciński Z., Śliwerski B. (eds.) (2019), Pedagogika. Podręcznik akademicki, Warszawa.

McDermott R. (ed.) (1984), The Essential Steiner: Basic writings of Rudolf Steiner, San Francisco.

Marcel G. (1962), Być i mieć, trans. P. Lubicz, Warszawa.

de Mooij M. (2013), Global Marketing and Advertising: Understanding Cultural Paradoxes, LondonNew York-Singapore.

Neill A.S. (1969), Theorie und Praxis der antyautoritären Erzienhung, Hamburg.

Paoluš R. (1991), K filosofii vychovy, Praha.

Raport Banku Światowego (2011), Fueling Growth and Competitiveness in Poland Through employment, skills and innovation, http://siteresources.worldbank.org/POLANDEXTN/Resources/304794-1300479015951/Europe2020Poland.pdf [access: 18.09.2017].

Raport Our Kids (2019), https://www.ourkids.net/pl/raport-o-szkolnictwie.php [access: 15.11.2019].

Rawls J. (1994), Teoria sprawiedliwości, Warszawa.

Robinson K. (2012), Zmiana paradygmatu edukacji, https://www.youtube.com/watch?v=_ wxcXd5Cnv8 [access: 15.11.2019].

Schaller K. (1977), Erziehung, „Wörterbuch der Pädagogik”, Bd. I.

Schulz L.E., Gopnik A. (2004), Causal learning across domains, „Developmental Psychology”, 40 (2), pp. 162-176, https://https://doi.org/10.1037/0012-1649.40 [access: 16.11.2019].

Seligman M.E.P., Csikszentmihalyi M. (2000), Positive psychology. A an introduction, „American Psychologist", 55 (1), pp. 5-14.

Śliwerski B. (2019), Pedagogika jako nauka, in: Pedagogika. Podręcznik akademicki, eds. Z. Kwieciński, B. Śliwerski, Warszawa.

Weller Ch. (2017), The first-ever robot citizen has 7 humanoid 'siblings' - here's what they look like, https:// www.businessinsider.com/sophia-robot-hanson-robotics-other-humanoids-2017-11?IR=T [access: 15.11.2019]. 